\title{
Chapter 5 \\ European Union's Democratic Legitimacy after the MoUs: The Political Legacy of an Economic Crisis
}

\author{
Dimitris Katsikas
}

\begin{abstract}
This chapter focuses on two significant aspects of crisis management in the Eurozone: (a) its democratic legitimacy and (b) its socioeconomic consequences. The two issues are very important, since both the socioeconomic effects of an adjustment program and its democratic credentials determine to a large extent its "ownership" by local societies and consequently its chances of success. Effectively, these two aspects refer to the "input" and "output" side of democratic legitimacy, that is, to legitimation through democratic processes and representation, and policy outcomes respectively. The analysis evaluates the first aspect of the legitimacy equation using criteria derived from democratic theory and applying them to the governance structure of the bailout programs. On the second aspect of legitimacy, that of outcomes, the socioeconomic consequences of the crisis management are reviewed, and their distributive aspects discussed. The chapter demonstrates that the EU's legitimacy has suffered along both aspects as a result of the crisis and the way it was handled. This leaves the EU in a particularly vulnerable state in the event of a future crisis.
\end{abstract}

\section{Introduction}

The European Economic and Monetary Union (EMU) proved the biggest victim of the global financial crisis that broke out in 2008. This was due to two factors: (a) the incomplete nature of the EMU and (b) the lack of a supranational crisis mechanism. By now, it is commonly acknowledged that before the crisis, significant imbalances had emerged among the economies of EMU's member states. Countries in the monetary union's periphery exhibited sluggish productivity growth which, coupled with high credit inflows, led to unsustainable current account deficits (Baldwin and

D. Katsikas $(\bowtie)$

National and Kapodistrian University of Athens and Hellenic Foundation for European and

Foreign Policy (ELIAMEP), Athens, Greece

e-mail: dkatsikas@eliamep.gr 
Giavazzi 2015). Investors from the capital-rich North directed their funds to profitable investments in the relatively capital-poor South. However, these capital flows did not fund productive investments; they were instead directed toward the nontradable sectors of these countries' economies, raising wages and inflation, undermining further their already weak international competitiveness, and boosting asset and real estate prices, thereby creating financial bubbles; in some countries, they were also used to fund mounting fiscal deficits. When, in the aftermath of the global financial crisis, there was a "sudden stop" of the capital flows, these countries had to face a harsh adjustment process. The EMU could not deal with such imbalances because of its flawed governance; its monetary pillar, built around the European Central Bank (ECB), had a clear institutional framework, a strong policy mandate and statutory independence from political interference. On the other hand, the remaining governance pillars were weak. In fiscal policy, the Stability and Growth Pact lacked enforcement powers and proved unable to control fiscal laxity in many member states (Begg 2011). Moreover, there was no supranational coordinating mechanism for the EU-wide stance of fiscal policy and its synchronization with ECB's monetary policy. In terms of broader economic policy surveillance, the Council's voluntary Broad Economic Policy Guidelines proved completely ineffective (Pisani-Ferry 2006). As a result, the EU lacked effective institutions with a clear mandate to prevent excessive imbalances.

Still, these imbalances did not have to lead to a full-blown regional debt crisis, which threatened the survival of the EMU itself. A major reason for this development was the absence of a crisis handling mechanism in the EMU, which led to an ad hoc, intergovernmental, and increasingly political handling of the crisis. In this context, "moral hazard" preoccupations prevailed; creditor countries worried that facilitating the recovery of crisis-hit countries would ease the pressure for fiscal adjustment and reforms. Such a rationale was also dictated by the politics of the time: bailing out crisis-hit countries that were depicted in the press as spendthrift and/or corrupt was not a particularly popular proposition, especially following the public bailouts of banks during the financial crisis only a couple of years earlier. The result was crisis management along an "individual responsibility" approach: every country needed to get its house in order (Katsikas 2012). This approach had two main characteristics:

(a) Individual bailout programs for each country that could not fund itself in the markets. The bailout loans were accompanied by conditionality; countries signed Memoranda of Understanding (MoUs), which spelled out the policy measures and structural reforms that had to be implemented in exchange for the funds. The design of the conditionality ${ }^{1}$ and the supervision of its implementation were the responsibility of the Troika, which comprised representatives of

\footnotetext{
${ }^{1}$ The design of the programs was decided together with the governments of the countries receiving the loans, which had the opportunity to propose measures of their own, particularly regarding the more detailed aspects of the policies put forward; having said that, the proposed measures had to be approved by the Troika.
} 
the creditors, namely, the European Commission, the ECB, and the International Monetary Fund (IMF). The reforms promoted had a liberal direction, aiming to improve the international competitiveness of these countries; in some cases, the MoUs also included comprehensive public administration reforms, with the aim to increase the efficiency and the fiscal sustainability of the state mechanism. It is worth noting that similar policies were promoted by countries which did not sign a bailout agreement, but faced similar problems, as was the case with Spain, which signed a more limited bailout agreement for its financial sector, and to a lesser degree, Italy.

(b) The cost of the adjustment process was entirely borne by the crisis-hit countries. The MoUs were the only way to deal with the crisis; there was no scope for any supranational mechanism of compensation for the economic and social losses of the adjustment process or for encouraging growth in the economies facing a deep recession, in large part, due to the promoted austerity policies. Some EU-wide growth funding initiatives, such as the Compact for Growth and Jobs agreed at the European Council of June 2012, were put forward but were never really implemented. An investment mechanism, the so-called Juncker Plan, was effectively put in place much later, after 2015, during the recovery of the European economy; it is worth noting that even this mechanism did not involve new public funding, but relied on the redeployment of already available funds in the EU budget and mainly the leveraging of new private funds.

This approach produced negative results not only for the affected economies but also for the cohesion and public support of the EU itself. The conditionality imposed through the MoUs in crisis-hit countries was extensive, ambitious, and in certain respects harsh, as was the case with the austerity policies promoted. This in turn caused or at the very least deepened the economic recession affecting the countries receiving the bailout funds. As a result, in the countries of the South, people living in adverse material circumstances felt alienated, disappointed, and increasingly angry by what they perceived to be a lack of solidarity by the European Union and the countries of the North, whom they often accused as responsible for the crisis. On the other hand, in the countries of Northern Europe, there was also a growing feeling of hostility developing toward the European project, as citizens questioned the decisions of their governments to "bail out" the countries of the South, which were often portrayed as "reckless" and "irresponsible." This rift, and more broadly the way the crisis was handled, ultimately undermined the legitimacy of the EU itself.

The aim of this chapter is to examine how the democratic legitimacy of the EU was affected by the crisis and the way this was handled, with a focus on the crisis-hit countries and particularly those of the European South. After a brief introduction in the issue of democratic legitimacy in the EU, different aspects of the crisis management will be analyzed, and their impact on the democratic legitimacy of the EU will be evaluated. 


\section{EU's Legitimacy Before the Crisis}

The political authority to issue rules and policy dictates necessitates legitimacy, that is, a sense of obligation on the part of the subjects of authority to conform to its pronouncements (Flathman 1980). Authority is not obeyed because people consider its individual decrees and rules to be always in their individual interest but due to a sense of obligation and an acknowledgement of the legitimate right of authority to issue commands and pronouncements. In this sense, legitimacy is a prerequisite not only for the effective operation but also for the very existence of political authority. ${ }^{2}$ In democratic regimes, this sense of obligation stems from the assurance that governments represent the people and that they will exercise their authority in ways which serve the people's interests in accordance with their values. These two aspects are often analyzed separately as two different forms of legitimacy: input and output legitimacy (Scharpf 1999; Schmidt 2013). ${ }^{3}$ Input legitimacy refers to processes which ensure the representation of the interests and values of the people in policymaking, primarily by establishing the accountability of policy-makers to the people, for example, through electoral processes. Output legitimacy refers to policy outcomes; legitimacy is ensured when the promoted policies do in fact serve the common good and improve the lives of the citizens. Political authority in democracies necessitates both types of legitimacy, but there is a trade-off; if a political entity is somewhat lacking in one dimension, it can "make it up" in the other dimension (Schmidt 2015).

Before the crisis, EU's record in terms of democratic legitimacy was mixed. Its input legitimacy was considered by many as lacking. Indeed, there was a lively academic debate about the so-called EU's democratic deficit (Weiler et al. 1995; Majone 1998; Moravcsik 2002, 2008; Follesdal and Hix 2006; Hix 2008). Follesdal and Hix (2006) summarized the arguments of the critics into five distinct claims, which referred to the strengthening of the executive power, at both the national and EU levels, at the expense of parliamentary control; the related weakness of the European Parliament and the absence of truly "European" elections; the distance of EU from the voters, who do not really understand and identify with it; and as a consequence of all the above, a "policy drift" away from voters' "ideal" policy preferences. Others objected to this critique; Andrew Moravcsik, one the leading scholars in EU studies, has rejected the democratic deficit theory as a myth, arguing that the EU is a limited-purpose organization which should not be held to an ideal standard of democracy more appropriate for nation states. Indeed, he believes that even

\footnotetext{
${ }^{2}$ This is true not only for democracy but for all kinds of government. What changes are the criteria based on which authority is judged; for example, in monarchies it could be blood lineage and the divine right, or in more primitive societies the sanctity of tradition. Having said that, the prolonged deterioration of people's living standards will ultimately erode authority, irrespective of its source. ${ }^{3}$ Vivien Schmidt has added another aspect of democratic legitimacy in her analysis, the so-called throughput legitimacy, which effectively refers to the quality of governance processes (e.g., transparency, inclusiveness, etc.). This aspect is not examined here.
} 
within the confines of its limited mandate, the EU "is at least as democratic, and generally more so, than its member states" (Moravcsik 2008, p. 332).

While Moravcsik may be right that the EU has a more limited mandate compared to national governments and that on the whole its function is subject to a - not inconsequential - array of democratic checks and balances, it is hard to deny the claim that the EU citizens do not understand or identify with the EU. Indeed, the very progress of European integration has been associated with the lack of citizens' participation; European elites have been thought to enjoy a "permissive consensus" by the general public, which allowed them significant leeway in promoting the project of European integration (Lindberg and Scheingold 1970). Democratization always came afterward in an effort to catch up with the integration progress, which was mainly driven by economic considerations (Fossum 2016).

In this context, the European integration process before the crisis was mostly driven by output legitimacy. As long as integration yielded economic benefits for the member states, it did not become an issue of strong political contestation in European societies. The advanced economies of the North took advantage of the benefits offered by the European single market to boost further their competitiveness and leverage the international presence of their companies, while the poorer countries of the South received significant economic aid in the form of structural funds, intended to help their economies adjust and gradually converge to those of the North. Later, the new entrants from Central and Eastern Europe also became beneficiaries of such funding and through their participation in the single market were able to link their economies to global value chains and receive substantial investment inflows. In this sense, before the crisis, the less than perfect record of the EU in terms of input legitimacy did not pose a major obstacle in European integration because the EU was thought to deliver prosperity to its citizens. ${ }^{4}$

\section{EU's Legitimacy After the Crisis}

The crisis undermined the legitimacy of the EU in a number of ways. The handling of the crisis raised serious concerns regarding its conformity to democratic norms, weakening further the already challenged input legitimacy of the EU. At the same time, the intensity and extent of the crisis, related to the austerity policies promoted through the MoUs, severely undermined its output legitimacy.

\footnotetext{
${ }^{4}$ Still, already before the crisis, problems in terms of legitimacy were becoming increasingly visible. The deepening and widening of the integration process that followed the Maastricht Treaty weakened the permissive consensus. European integration became increasingly intertwined with issues pertaining to core aspects of national sovereignty and identity, making it more controversial and politicized, and thus increasingly part of domestic party politics; as a result, it gradually started becoming subject to an intensifying "constraining dissensus" (Hooghe and Marks 2009).
} 


\section{EU's Input Legitimacy and the Crisis}

Turning first to the issue of input legitimacy, the MoUs and the Troika challenged democratic norms of policy-making at both the national and EU levels. More specifically, at the EU level, the institutional set-up and operation of the Troika and the policies promoted through the MoUs produced a number of challenges for democratic legitimacy. First, the Troika was an ad hoc institutional mechanism, created in haste to deal with the crisis. This created several problems: there were no established procedures, in relation to the other EU institutions and in particular the European Parliament, which could increase the democratic accountability of its operation. Moreover, the IMF, being an international economic organization, had no obligation to inform or report to European institutions about its actions and decisions in the context of the Troika. All in all, there was lack of transparency in Troika's decision-making which undermined its accountability. Moreover, the Troika had no legal mandate stemming from the EU Treaties and no clearly defined objective. As a result, procedures were followed which did not have any legal basis, putting in doubt not only the legitimacy but also the legality of its actions; for example, Eurogroup's mandate to the European Commission to negotiate on its behalf the details of the bailout programs with the countries receiving the loans was legally unfounded, as such a procedure is not specified in EU law and because the Eurogroup is not an official EU body (European Parliament Report 2014, p. 16). ${ }^{5}$

Secondly, Troika's composition was highly problematic: both the European Commission and the European Central Bank faced serious conflicts of interest. More specifically, as part of the Troika, the European Commission was acting as an agent of the member states, which had authorized it to negotiate and supervise the implementation of the bailout programs. At the same time, the European Commission is considered the "guardian of the Treaties," the supranational organ entrusted to supervise the application of EU laws and norms. In other words, the European Commission came to act as both the agent and the "supervisor" of national governments, and more often than not, this conflict worked at the expense of the latter role, which however is the one institutionally assigned to the European Commission. Moreover, in terms of the MoUs' policy content, the bailout programs' conditionality extended to policy areas such as healthcare, labor, and social policy, which for the most part are outside the remit of EU policy competence. In addition, many of the policies promoted violated either directly or indirectly, through their results, the principles enshrined in essential EU legal texts such as the Charter of Fundamental Rights of the EU or strategic policy agendas like "Europe 2020," exposing once again the untenable position of the Commission as both the guardian and violator of EU principles.

Similar problems were also raised with relation to ECB's role in the Troika, as its role extended well beyond its mandate regarding monetary policy. Indeed, the ECB

\footnotetext{
${ }^{5}$ Regulation (EU) No 472/2013 changed this, as it provided an institutional basis for the operation of the Troika.
} 
was involved in decisions relating to fiscal, wage, and financial policies and structural reforms in a number of policy areas, all of which were well outside its authority. These decisions had often significant distributional consequences (e.g., its decision not to bail in the senior-bondholders of the Irish banks in 2010), were employed by the Troika as leverage during the negotiations of the bailout agreements (e.g., the threatened termination of emergency liquidity assistance in the cases of Ireland and Cyprus in 2010 and 2013, respectively, and its actual termination in the case of Greece in early 2015), and/or constituted direct interventions in the political system of the countries in crisis, as was the case with the letters sent by the ECB to the governments of Spain, Italy, and Ireland. These actions proved controversial and had clear political ramifications, which undermined the status of the ECB and its credibility as a central bank independent from politics. What is more, the ECB's accountability framework was not appropriate for this kind of political decision-making, which further undermined the legitimacy of these decisions (Transparency International EU 2017).

The problems with the Troika's institutional set-up were not unrelated to the new mode of EU's operation during the crisis. In the course of the crisis, decisions were increasingly taken in the context of a renewed intergovernmentalism, where the European Council took the decision-making initiative and the Eurogroup acted as its "legislative-executive arm," setting out more detailed guidelines for the European Commission. The latter, in its role as the initiator of EU policies and the European Parliament as a co-decision agent and an accountability mechanism, were largely sidestepped. It is telling that both of EU's funding mechanisms, the European Financial Stability Facility (EFSF) and the European Stability Mechanism (ESM), were created on the basis of intergovernmental agreements, outside the EU legal framework. The same is true for one of the most important reforms of the EU's economic governance following the crisis, the so-called Fiscal Compact. Intergovernmental bargaining meant that the creditor countries, enjoying a highly asymmetrical negotiating advantage, came to dictate the terms of the bailout agreements according to their national preferences (Schimmelfennig 2015). In this context, established EU rules, norms, and practices often took second place in the negotiating table.

Beyond undermining democratic legitimacy at the EU level, the dominance of creditor countries' preferences in the design and implementation of bailout agreements affected negatively the input legitimacy of the MoUs in crisis-hit countries as well. The perception that the policies contained in the MoUs, and more generally the terms of the agreements, were dictated by the countries of the North and imposed on the countries in the South receiving the loans undermined from the beginning the "ownership" of the programs. ${ }^{6}$ According to the IMF itself, ownership is a key factor for the success of a bailout program (IMF 2006). If the prevailing perception in

\footnotetext{
${ }^{6}$ According to the IMF, "National ownership refers to a commitment to a program of policies, by country officials who have the responsibility to formulate and carry out those policies, based on their understanding that the program is achievable and is in the country's best interests" (IMF 2006, p. 1).
} 
a country is that conditionality is externally imposed, or that the program serves the interests of particular interest groups, in or even out of the country (Gould 2003), then opposition to the program conditionality is likely to be high, particularly when the proposed measures inflict economic losses on large parts of the population, as was the case with the MoUs' austerity and internal devaluation policies.

Moreover, opposition can be high against structural reforms. Structural reforms have distributional consequences, which can produce resistance not only from those that know that they stand to lose but also from broader population groups, which face uncertainty over the distribution of costs and benefits and opt for the risk-averse solution of the status quo (Fernández and Rodrik 1991). The MoUs promoted reforms, which were unrealistically ambitious, anticipating major restructuring in a wide array of policy areas, ranging from the labor and product markets to public administration and the welfare state, in a short period of time. This created uncertainty, disrupting further the depressed economies, undermined the effectiveness of the reforms, and created losers who resisted the MoUs' conditionality. The combined effect of austerity and structural reforms, in combination with the widely shared, and largely accurate, impression that the MoUs were imposed by the creditor countries, completely undermined ownership of the promoted policies; in other words there was a lack of socio-political consensus for the promoted policies, which for large parts of the population rendered them effectively "unauthorized" (Bellamy and Weale 2015).

This impression was progressively strengthened by the fact that the same kinds of policies were promoted despite the alternation of parties with different ideological orientation in government. It was as if it did not matter which government was in power; elections produced different governments, but not different policies. This effectively "hollowed out" the domestic political process, resulting in what has been termed "politics without policy" (Schmidt 2015) or "politics of constrained choice" (Laffan 2014). This political impression took on a substantive institutional manifestation in the way national parliaments operated during the crisis. The functioning of national parliaments became hostage to a permanent "state of emergency," which allowed incumbent governments to pass bills with limited parliamentary oversight under emergency procedures, which effectively forbade a comprehensive discussion of the proposed measures; in effect parliaments became rubber-stamping institutions for policies decided in intergovernmental negotiations at the EU level, while in some cases they were completely by-passed, as was the case in Portugal where the MoU was not brought to parliament for ratification. The continuous erosion of MoUs' input legitimacy undermined public trust in domestic political systems, which in turn created space for the emergence of populist and Eurosceptic parties. In other words, the way the crisis was handled undermined not only the democratic legitimacy of the EU but also that of the domestic political institutions, raising concerns about the quality and operation of democracy in crisis-hit countries. 


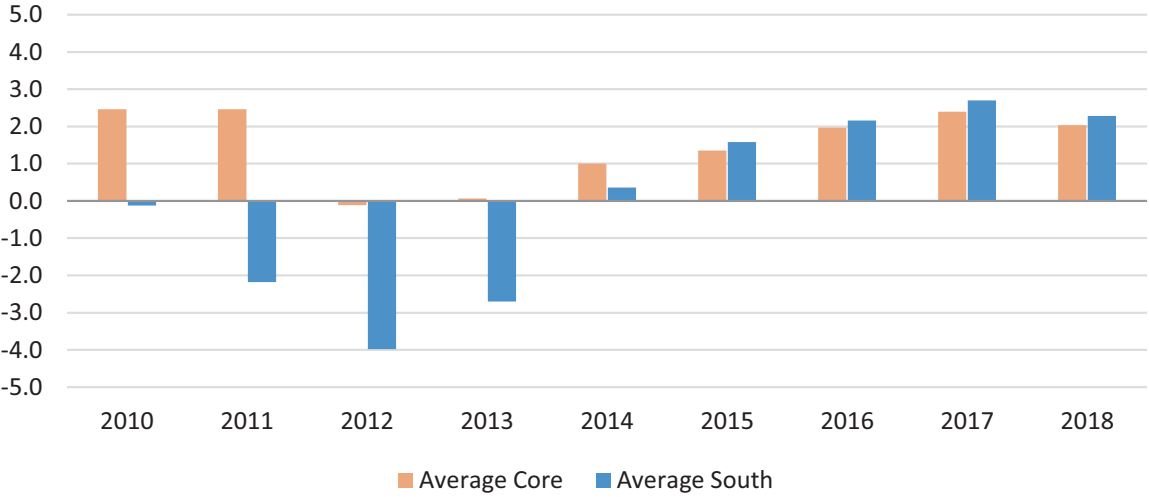

Fig. 5.1 Average growth rates in the EU Core and in the EU South (gross domestic product at market prices, chain linked volumes, percentage change on previous period, 2010-2018). Note: Core countries include Austria, Belgium, Finland, France, Germany, and the Netherlands; "South" countries include Cyprus, Greece, Italy, Portugal, and Spain. (Source: Author's elaboration of Eurostat data)

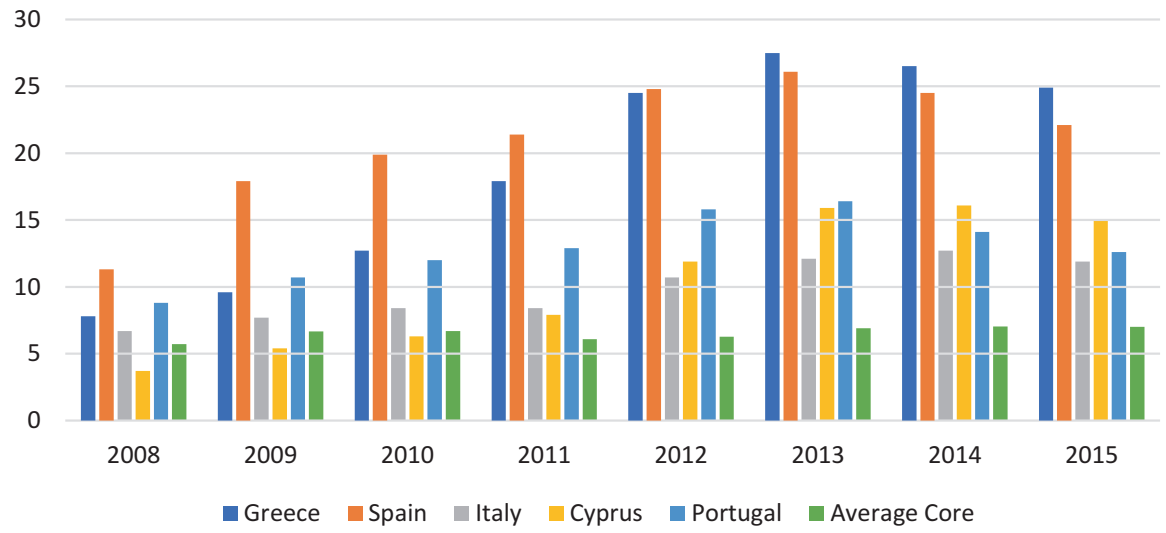

Fig. 5.2 Unemployment rate, countries of the EU South and average EU Core (\% active population, 2008-2015). (Source: Author's elaboration of Eurostat data)

\section{The Impact of the Crisis and EU's Output Legitimacy}

The erosion of input legitimacy due to the policies promoted under the MoUs could have been perhaps tolerated by the publics in crisis-hit countries, if these measures improved their economic situation. On the contrary, the policies promoted produced severe negative short-term economic consequences, which undermined the hitherto strong pillar of EU's democratic legitimacy, that of output legitimacy.

The austerity and internal devaluation policies led to a sharp decline of disposable income and economic activity, which sent the crisis-hit economies into 
recession (Fig. 5.1). ${ }^{7}$ The negative income shock was combined with problems in the banking sector, already ailing from the global financial crisis, and long-term structural weaknesses that kept productivity and international competitiveness low. These problems made recovery difficult, particularly as the Troika persisted in setting unrealistic fiscal targets, which did not take into account the effects of the recession, necessitating thereby new austerity measures, a process which drove economies into a downward economic spiral. As a result, unemployment rates rose fast, often reaching unprecedented levels, as was the case in Greece and Spain (Fig. 5.2). The situation in the labor market was in sharp contrast with that of the countries of the "core," which experienced mild increases in their unemployment rate if at all (e.g., Germany's unemployment rate kept falling from 2010 onward and throughout the crisis).

The large numbers of unemployed people in turn meant a deterioration of their material circumstances, made worse by the well-known weaknesses of the welfare systems in the countries of Southern Europe (Ferrera 1996). In addition to fragmentation and operational inefficiencies, the welfare system in these countries struggled to cope financially, under circumstances of declining income flows as a result of reduced insurance contributions (due to the rising unemployment) and state funding (due to austerity policies), while needs for expenditures rose (e.g., for

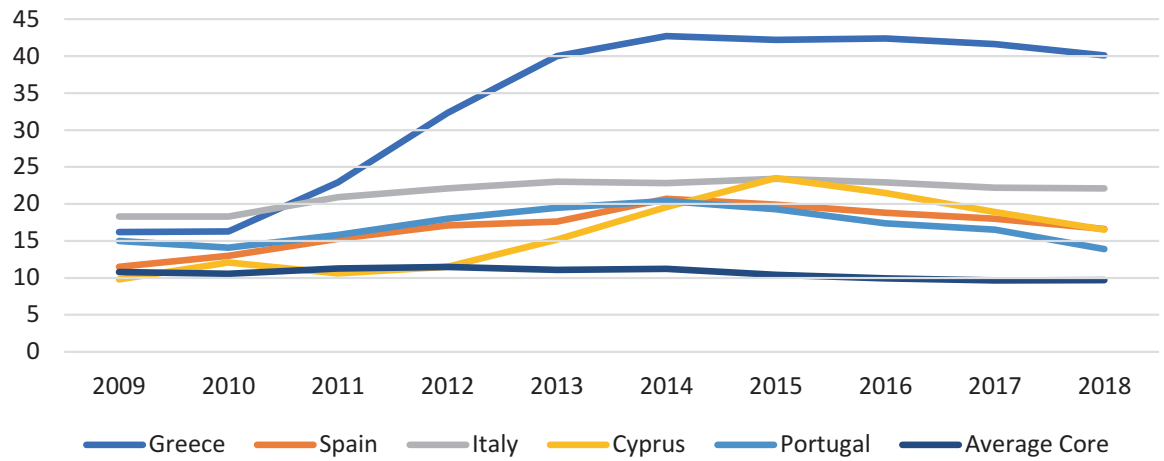

Fig. 5.3 At-risk-of-poverty rate anchored at a fixed moment in time (2005) by age and sex, countries of the EU South and average EU Core (\% of the population 2009-2018). Note 1: A fixed poverty line measures poverty compared to a fixed level of income which does not change through time. A fixed poverty line can be a very useful analytical tool in cases of big and rapid positive or negative changes in economic output in a country. In such circumstances there is a tendency for the entire distribution to move upward (or downward), leaving thus relative poverty largely unchanged. Accordingly, in such circumstances it makes sense to compare peoples' level of living not with other people in the same society, but with the same peoples' living circumstances of only a few years ago, before the boom (crisis) took hold.). Note 2: The "average core" excludes France due data unavailability. (Source: Author's elaboration of Eurostat data)

\footnotetext{
${ }^{7}$ The graph does not include Ireland due to some uncertainty regarding its GDP statistics, particularly during the recovery period after 2015. See, for example, Halpin (2016).
} 
unemployment benefits). As a result, levels of poverty and/or social exclusion started to rise substantially, Greece being in a category of its own (Fig. 5.3). The result was a social crisis, which fed further people's anger, contributed to the delegitimation of domestic political systems and the quest for alternative solutions, often found in the rhetoric of populist parties.

Why did the creditors insist on policies that sent the crisis-hit economies in recession and stirred social and political turmoil? The answer lies in the way the crisis was handled; the intergovernmental and highly political handling of the crisis led to bailout programs whose overriding priority was the reduction of fiscal deficits and the sustainability of public debt. The reasons for this were twofold: firstly, the obvious desire of creditors to limit their funding to debtor countries, in order to safeguard their own fiscal integrity, but most importantly to address the concerns that dominated domestic political discourse about using taxpayers money to bail out the "irresponsible" partners in the South; secondly, to limit the "moral hazard" associated with bailing out the countries in crisis, that is, the danger that they would become dependent on such financing and relax their fiscal consolidation and reform efforts.

The desire to limit moral hazard was evident in the rhetoric adapted to justify the proposed policies; the crisis was typically presented as one of fiscal profligacy on the part of the debtor countries, which does not stand up to scrutiny given the solid fiscal record of countries like Ireland and Spain before the global financial crisis. Nonetheless this became the dominant narrative in the early stages of the crisis and affected the design of the programs, which emphasized front-loaded austerity and a "big-bang" of structural reforms. This unavoidably led to a "one-size-fits-all" approach, which proved problematic because there was disregard for the distinct features of these economies, as well as for the different causes of the crisis in different countries. As a result, Troika's projections proved highly erroneous (typically over-optimistic) and led to the oft-cited IMF's acknowledgement of its failure to calculate properly the fiscal multipliers (Blanchard and Leigh 2013), on which the design of austerity policies had been based. Similar mistakes were repeated in the area of structural reforms, where knowledge of local economic realities but also of political and institutional characteristics are more important. Rodrik (2016) has criticized the ambitious "big-bang" programs, which eventually resulted in micromanagement of the economy and/or the public service, costing precious political capital while producing moderate economic results.

The internal devaluation policies are a case in point; one of the factors that may account for the very different trajectories of Greece and Ireland during the crisis is the fact that Ireland's labor and product markets were considered flexible and dynamic before the crisis, which maximized the benefits of the internal devaluation policy that was adopted; in Greece on the other hand, the internal devaluation policy did not yield similar results, given the closed nature of the economy and the structural rigidities in the product and labor markets (see, e.g., Zografakis and Kastelli 2017). Indeed, it seems that in Greece, the focus on internal devaluation led to a sequencing of reforms in the labor and product markets which proved 
counter-productive in terms of economic results (Petralias et al. 2018), but highly disruptive in terms of its social and political repercussions.

All these problems were not new; they have all been documented before in the literature on the IMF, which has also been criticized for the "one-size-fits-all" approach (e.g., Stiglitz 2002; Ostry et al. 2016) and for biased, typically overoptimistic, projections (e.g., Atoyan and Conway 2011). Despite this knowledge and previous experience, the same mistakes were repeated causing social, political, and institutional backlash which not only undermined the effectiveness of the reforms but also strengthened Eurosceptic rhetoric, attitudes, and parties.

\section{Conclusions}

Before the crisis, EU's democratic legitimacy record was mixed. Its input legitimacy was challenged from many quarters, but European integration continued to progress given the material prosperity it was thought to deliver to Europeans. The crisis delivered a blow to the democratic legitimacy of the EU. Its already challenged input legitimacy suffered further, as the ad hoc, intergovernmental, and increasingly political handling of the crisis violated EU norms and institutions. The resulting policies were forced on crisis-hit member states, with limited parliamentary scrutiny and democratic debate, hollowing out the domestic political systems. Such practices created space for anti-systemic and Eurosceptic populist parties, which gained strength in a number of member states.

In recent years, economic recovery has improved the image of the EU once again, confirming to some degree the output legitimacy hypothesis. However, significant challenges remain. While the image of the EU has almost fully recovered, trust in the EU is still well below its pre-crisis levels for most countries (see Chap. 16, of Verney and Katsikas, this volume). Moreover, the damage to the credibility and legitimacy of domestic political institutions is harder to overcome; the refugee crisis of 2015-2016 added strength to the rise of populist, Eurosceptic, and nationalistic parties, not only in the crisis-hit countries but also in the countries of the North. Moreover, the economic and social consequences of the crisis are still not fully overcome in most of the crisis-hit countries. This increases their vulnerability to the effects of a new international or European crisis; indeed, such fears are on the rise again given the slowdown in the world and European economy in 2018 and 2019. In sum, while the EU was able to overcome the crisis, the way this was handled has left a negative legacy of political mistrust toward both the EU and the domestic political systems, which has undermined their democratic legitimacy. Given the additional pressures that have arisen due to the refugee crisis and the growing discontent about the effects of globalization, this legacy may be more lasting and consequential than it currently appears. 


\section{References}

Atoyan, R., \& Conway, P. (2011). Projecting macroeconomic outcomes: Evidence from the IMF. Review of International Organizations, 6(3), 415-441.

Baldwin, R., \& Giavazzi, F. (Eds.) (2015). The Eurozone Crisis: A consensus view of the causes and a few possible solutions. A VoxEU.org eBook, CEPR Press.

Begg, I. (2011). Prevent or cure? Dilemmas facing economic governance. In I. Begg, A. Belke, S. Dullien, D. Schwarzer, \& R. Vilpišauskas (Eds.), European economic governance: Impulses for crisis prevention and new institutions. Bertelsmann Stiftung. https://www.yumpu.com/en/ document/view/49720762/european-economic-governance-bertelsmann-stiftung. Accessed 30 Oct 2019.

Bellamy, R., \& Weale, A. (2015). Political legitimacy and European monetary union: Contracts, constitutionalism and the normative logic of two-level games. Journal of European Public Policy, 22(2), 257-274.

Blanchard, O., \& Leigh, D. (2013). Growth forecast errors and fiscal multipliers. American Economic Review, 103(3), 117-120.

European Parliament. (2014). Report on the enquiry on the role and operations of the Troika (ECB, Commission and IMF) with regard to the Euro area programme countries (2013/2277(INI)), Committee on Economic and Monetary Affairs, A7-0149/2014, 28.2.2014. https://www. europarl.europa.eu/cmsdata/59739/att_20140305ATT80482-1284267003893663985.pdf Accessed 30 Oct 2019.

Fernández, R., \& Rodrik, D. (1991). Resistance to reform: Status quo bias in the presence of individual-specific uncertainty. American Economic Review, 81(5), 1146-1156.

Ferrera, M. (1996). The "southern model" of welfare in social Europe. Journal of European Social Policy, 6(1), 17-37.

Flathman, R. E. (1980). The practice of political authority: Authority and the authoritative. Chicago and London: The University of Chicago Press.

Follesdal, A., \& Hix, S. (2006). Why there is a democratic deficit in the EU: A response to Majone and Moravcsik. Journal of Common Market Studies, 44, 533-562.

Fossum, J. E. (2016). Democracy and Legitimacy in the EU: Challenges and Options. IAI Working Papers 16. http://www.iai.it/sites/default/files/iaiwp1601.pdf. Accessed 30 October 2019.

Gould, E. R. (2003). Money talks: Supplementary financiers and international monetary fund conditionality. International Organization, 57, 551-586.

Halpin, P. (2016, July 13). Leprechaun economics' leaves Irish growth story in limbo. Reuters. https://www.reuters.com/article/us-ireland-economy/leprechaun-economics-leaves-irishgrowth-story-in-limbo-idUSKCNOZT21K. Accessed 10 Nov 2019.

Hix, S. (2008). What's wrong with the European Union and how to fix it. Cambridge: Polity Press.

Hooghe, L., \& Marks, G. (2009). A post-functionalist theory of European integration: From permissive consensus to constraining dissensus. British Journal of Political Science, 39(1), 1-23.

International Monetary Fund. (2006). Statement of the IMF Staff principles underlying the guidelines on conditionality, Revised January 9. https://www.imf.org/external/np/pp/ eng/2006/010906.pdf. Accessed 20 Sept 2019.

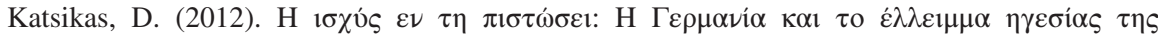

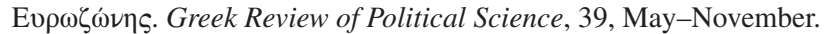

Laffan, B. (2014). Testing times: The growing primacy of responsibility in the Euro area. West European Politics, 37(2), 270-287.

Lindberg, L. N., \& Scheingold, S. A. (1970). Europe's would-be polity: Patterns of change in the European community. Englewood Cliffs, N.J: Prentice-Hall.

Majone, G. (1998). Europe's 'democratic deficit': The question of standards. European Law Journal, 4(1), 5-28.

Moravcsik, A. (2002). Reassessing legitimacy in the European Union. Journal of Common Market Studies., 40(4), 603-624. 
Moravcsik, A. (2008). The myth of Europe's democratic deficit. Intereconomics: Journal of European Public Policy, (November-December), 331-340.

Ostry, J. D., Loungani, P., \& Furceri, D. (2016). Neoliberalism: Oversold? Finance and Development, June, 38-41.

Petralias, A., Anastasatou, M., \& Katsikas, D. (2018). Balancing adjustment policies and structural reforms in Greece: The case of product markets. In P. Manasse \& D. Katsikas (Eds.), Economic crisis and structural reforms in southern Europe: Policy lessons. London and New York: Routledge.

Pisani-Ferry, J. (2006). Only one bed for two dreams: A critical retrospective on the debate over the economic governance of the Euro area. Journal of Common Market Studies, 44(4), 823-844.

Rodrik, D. (2016). The elusive promise of structural reform. Milken Institute Review, 18(2), 26-35.

Scharpf, F. W. (1999). Governing in Europe. Oxford: Oxford University Press.

Schimmelfennig, F. (2015). Liberal intergovernmentalism and the Euro area crisis. Journal of European Public Policy, 22(2), 177-195.

Schmidt, V. A. (2013). Democracy and legitimacy in the European Union revisited: Input, output and 'throughput'. Political Studies, 61, 2-22.

Schmidt, V. A. (2015). The Eurozone's crisis of democratic legitimacy: Can the EU rebuild public trust and support for European economic integration. Discussion Paper 015, September, European Economy, European Commission. https://ec.europa.eu/info/sites/info/files/dp015_ en.pdf. Accessed 30 Aug 2019.

Stiglitz, J. E. (2002). Globalization and its discontents. New York: Norton.

Transparency International EU. (2017). Two sides of the same coin? Independence and accountability of the European Central Bank. https://transparency.eu/wp-content/uploads/2017/03/ TI-EU_ECB_Report_DIGITAL.pdf. Accesses 20 Sept 2019.

Weiler, J. H. H., Haltern, U. R., \& Mayer, F. (1995). European democracy and its critique. West European Politics, 18(3), 4-39.

Zografakis, S., \& Kastelli, I. (2017). Is it true that reducing labour costs is sufficient to improve the competitiveness of the Greek economy? In D. Katsikas, K. Filinis, \& M. Anastasatou

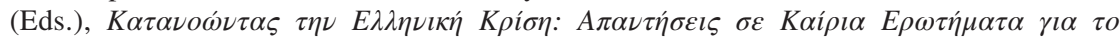

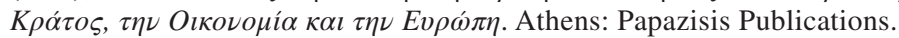

Open Access This chapter is licensed under the terms of the Creative Commons Attribution 4.0 International License (http://creativecommons.org/licenses/by/4.0/), which permits use, sharing, adaptation, distribution and reproduction in any medium or format, as long as you give appropriate credit to the original author(s) and the source, provide a link to the Creative Commons license and indicate if changes were made.

The images or other third party material in this chapter are included in the chapter's Creative Commons license, unless indicated otherwise in a credit line to the material. If material is not included in the chapter's Creative Commons license and your intended use is not permitted by statutory regulation or exceeds the permitted use, you will need to obtain permission directly from the copyright holder.

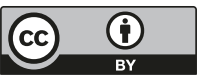

